\title{
Study on the Path of Integrating Strictly and Ruling Party into Teaching of Introduction Courses
}

\author{
Yu He \\ Sichuan Agricultural University, Chengdu, Sichuan, 611130
}

Keywords: Four comprehensive; comprehensive and strict party; "Introduction" class; teaching

\begin{abstract}
The "Introduction to Mao Zedong Thought and the Theoretical System of Socialism with Chinese Characteristics" is the core curriculum of the four compulsory courses of ideological and political theory in universities, which can fully embody the theoretical results of the sinicization of Marxism. General Secretary Xi Jinping's "four comprehensiveness" based on the overall situation of national reform, development and stability is an innovative achievement combining the Marxism with the practice of China and should be integrated into the teaching process of the "Introduction" class. Through the integration of the teaching content of "Introduction", integrating the "four comprehensiveness" into the six thematic lectures, it can effectively bring into play the special role of "Introduction" in the "four comprehensive" propaganda and ideological work as well as the promotion of "Introduction" The overall efficiency and effectiveness of teaching.
\end{abstract}

\section{Introduction}

General Secretary Xi Jinping pointed out on many occasions that a comprehensive and strict party rule will always be on the road. Party organizations at all levels should shoulder the responsibility of completely and strictly administering the party. To comprehensively and strictly administer the party, the core is to strengthen the party's leadership. The foundation is comprehensive, the key is to be strict and the key is to rule. The important speech of the general secretary further proclaimed the firm confidence and courage of the party Central Committee in completely and strictly administering the party and forging a strong leadership core. Full and strict administration of the party is the fundamental guarantee for our party to carry out the great struggle with many new historical features under the new situation. It is the fundamental guarantee for realizing the goal of "two hundred and 100 years" and the Chinese dream of the great rejuvenation of the Chinese nation. To govern the country must first rule the party, and the party must be strict. The purpose of comprehensively and strictly administering the party is very clear: we must focus on strengthening the party's leadership as the fundamental solution to the problem of losing the party member a wide control, losing control to relaxation and losing everything to softness, and ensuring that the party has always become a socialism with Chinese characteristics Career leadership strong core.

\section{The Significance of "Fully and Strict Management of the Party" in the Teaching of "Introduction"}

Comprehensive and strict administration of party ideology into the ideological and political teaching, to guide college students to fully understand the anti-corruption struggle long-term and complex; recognize our party's zero tolerance of corruption, a firm attitude; Correct view of "anti-corruption theory" and "power Struggle theory "; establish an awareness of discipline, the awareness of the rule of law, compliance with discipline, strict discipline and other aspects of the important practical guidance.

The "four comprehensive" strategic layout is proposed by the Central Party Committee headed by General Secretary Xi Jinping to profoundly summarize the theoretical system of socialism with Chinese characteristics in practice and exploration, greatly develop the achievements of the theory of Marxism in China and realize the theory of socialism with Chinese characteristics System of new 
sublimation and leap. The "four comprehensive" strategic layout is an important part of the CPC Central Committee's strategy of running the country with Comrade Xi Jinping as its general secretary. It reflects the glorious ideology of combining Marxism with the reality of China and embodies Marxist positions, views and methods. As an important front for training qualified personnel for the development of the cause of socialism, colleges and universities should put the important thinking of further promoting the strategic layout of the "four holistic" strategies into teaching materials, into the classroom and into the mind as an important task in the present teaching of ideological and political theory. Only into the textbooks, to enter the classroom; only into the classroom, in order to enter the mind of college students; the only way to truly brain, heart. At this stage, colleges and universities, as the "main force" for propagandizing and implementing the "four comprehensive" strategic layout, should profoundly understand and accurately grasp the scientific connotation and development laws of the "four comprehensive" strategic layout and profoundly understand and accurately grasp the theory of Marxism in China The latest development of this research. It can be said that a comprehensive understanding and strengthening of the "four comprehensive" strategic layout into the classrooms of colleges and universities is an inevitable requirement for realizing the great rejuvenation of the Chinese dream of the Chinese nation and is the proper meaning of ideological and political education in colleges and universities as dissemination of the latest research results of Marxism in China.

Students are flourishing and are at an important stage in the formation of a world outlook, outlook on life and values, but they are also easily affected by some negative and negative factors brought about by the prosperous market economy. Since the reform and opening up, profound changes have taken place in our economic structure, profound changes in social structure, profound adjustments in the pattern of interests and profound changes in ideology. All these important changes and the important performance of social differentiation all affect the ideological consciousness of contemporary college students. Especially in the advent of the Internet age, various multicultural cultures permeate each other and spread rapidly, which seriously affects or even interferes with the ideological trends of contemporary college students. The course of ideological and political theory in colleges and universities is the main carrier of carrying out the important thought of "four comprehensives" strategic layout. The workers of ideological and political education in colleges and universities should shoulder their historical responsibility further so as to enable students to comprehend the essence and intension of the important thinking of the "four comprehensive" strategic layout, this will inevitably help college students to objectively understand the basic national conditions of our country and the tremendous historical achievements made during the course of reform and opening up. It is also conducive to improving the status quo of ideological and political education in colleges and universities. It is conducive to learning and understanding of the latest policy trends of the party in colleges and universities. Ideological and political quality, and continuously enhance the patriotic feelings of college students. It is also conducive to implementing the core values of socialism and creating the conditions for cultivating highly qualified personnel capable of all-round development in moral, intellectual, physical and aesthetic capacities and successors to socialism with Chinese characteristics.

Since the 18th CPC National Congress was held, the Central Commission for Discipline Inspection has in-depthly pushed forward the party's discipline inspection system reform and mass attacked. It firmly punished "tigers" and "flies" with a zero-tolerance attitude and eliminated the cancer that breeds on the party's healthy body. Safeguarding the party's unity and unification, and purifying the party's organization and team, and achieved remarkable results. However, we must also be soberly aware that the system of rules and regulations within the party is still not sound, that the soil and environment that breed corruption still exist and that the situation in the struggle against corruption remains serious

Jun complex, with long-term and complex features, therefore, anti-corruption struggle will always be on the road.

At present, the situation in which the anti-corruption struggle is not decadent is taking shape. The trend of corruption has basically been reversed and the style of the party's work style has been 
greatly improved. However, the situation in the fight against corruption is still grave and complicated, and the soil and environment that breed corruption still exist. The fight against corruption is only ongoing and not completed. It is necessary to resolutely investigate and deal with cases involving discipline and law-breaking by leading cadres, and also earnestly solve the corruption that has taken place alongside the masses. Guide college students to recognize the party Central Committee's resolute zero-tolerance attitude towards corruption. As General Secretary Xi Jinping once pointed out: "The determination of the party Central Committee to unswervingly oppose corruption has not changed. The goal of resolutely curbing the trend of the spread of corruption has not changed."

The contemporary college students are the future of the motherland, the main force for building the great cause of socialism with Chinese characteristics, and the backbone for realizing the great dream of rejuvenating China. In the teaching of Introduction to the Party, through the solemnization of the party's ideology, the Central Party Committee has stated its determination and courage in fighting against corruption: sticking to the "tiger" and "flies" to fight together, no matter what kind of people and no matter how high their positions, anyone who violated the party discipline and state laws must find out in the end and never give up. Therefore, it is conducive to promoting college students to establish their awareness of discipline and rule of law, to be disciplined and disciplined, to be self-disciplined, and to regard discipline and law as the bottom line of everyday learning and life. There are reliable builders and successors in the great cause of socialism with Chinese characteristics.

\section{The spirit of the Sixth Plenary Session of the "General" class teaching the practical problems facing}

For universities, the implementation of the "four comprehensive" strategic layout means that the essence of the "four comprehensive" thinking should be implemented into the concrete practice of promoting the reform and development of the school undertaking and performing the social functions of the university. [5] However, at present, although some of the political, ideological and political teaching materials embody the "four comprehensives" in studying and implementing the "four comprehensive" strategic layouts, Chinese universities are not enough to promote their basic connotation and substantive content. Further strengthen mission and leadership. As far as the current situation is concerned, there are still some problems in the ways and means of learning, implementing and understanding the "four comprehensive" strategic layout of colleges and universities, which are mainly reflected in the following aspects: the curriculum of colleges and universities, the arrangement of teaching contents, the construction of teachers' teams, Atmosphere, etc., the specific performance in the following points.

The important form and link of ideological and political theory education and teaching are classroom teaching. The "Four All-round" strategic layout should "enter the teaching materials, enter the classroom and enter the head". Among them, "into the classroom" is undoubtedly a central link. University teachers must make great efforts in how to further promote the "four comprehensive" strategic layout into the classroom. However, some colleges and universities in our country have always attached great importance to the curriculum of students' specialized courses, and the supply of specialized courses is sufficient in terms of hours. According to the setting of theoretical courses of ideological and political theory, there are generally few classes, large classes and large numbers of students. Sex, and highly specialized small class teaching effect can not be compared, is not conducive to reflect the teaching content is not conducive to the interaction of teachers and students in teaching, it is difficult to guarantee and achieve a certain educational effect and teaching purposes. In addition, as the leader of classroom teaching, teachers must fully tap the substantive connotation of the strategic layout of "four comprehensives" in lesson preparation process. Some teachers do not thoroughly understand the content system of "four comprehensive" To help students understand and correctly grasp the great significance of the "four comprehensive" strategic layout? Therefore, we should scientifically and reasonably arrange the ideological and political course in colleges and universities, and continuously strengthen the building of the 
teaching staff. Only by integrating the content system of the "four comprehensive" strategic layout into the minds of the ideological and political teachers first is it possible to integrate them into the classroom teaching system in the meantime, students should be guided to grasp and grasp the strategic layout of "four comprehensives," so that the actualization of the "four comprehensives" in the classroom of the university can be truly effective.

Teaching materials is an important basis for teaching and learning. Although the basic concept of "four comprehensiveness" has been compiled into a teaching material for ideological and political education, especially in the teaching of "general introduction", some colleges still lack suitable thematic teaching materials that reflect the contents of the "four comprehensive" strategic layout This has become a key issue for the contents of the course of ideological and political theory in higher education institutions not to be better integrated with the spirit of "four comprehensiveness." As the saying goes, "clever women make bricks without straw" and strengthen the "four comprehensive" strategic layout into college classrooms, we must make great efforts into teaching materials, which is also the focus of this work. Only in the teaching content and the "four comprehensive" strategic thinking are closely integrated, it is possible to enter the classroom, into the student mind. As the latest achievement of the development of Marxism in China, the "four comprehensive" strategic layout is the planning and practice requirement for the reform and development of the party and state in the new period. Without a unified teaching material, it is difficult to carry out the "four comprehensive" strategic layout in teaching Content and requirements [6]. Therefore, we should make full use of the important platform of ideological and political theory education, use educational experiences and methods combining practice and theory to update teaching materials in time and promote the strategic layout of "four comprehensive strategies" into teaching materials so that students can fully understand The Essential Connotation and Spiritual Meaning of "Four Comprehensive" Strategic Layout.

Keeping Pace with the Time is an Important Feature of Ideological and Political Education in Colleges and Universities. Therefore, the ideological and political education of college students should have the characteristics of the times, advanced. At present, some colleges and universities do not fully grasp the characteristics of contemporary college students in carrying out the strategic layout of "four comprehensives". The teaching methods are dull and boring. They simply insist on traditional forms of instilling education. They do not have the requirements of class discussion and practice and are hard to inspire and arouse students' interests. Not "into the head" of the effect and role. The ideological and political education workers in colleges and universities should implement the spirit of advancing with the times in implementing the entire process of ideological and political education and include the content and essence of the "four comprehensiveness" in the ideological and political education of college students, Going in all aspects of life [7]. Ideological and political workers in colleges and universities should learn to analyze the characteristics of ideological and political education in colleges and universities in the new situation, fully understand the ideological reality of college students, research and explore new problems and new situations in teaching, and focus on the hot issues of employment, combating corruption and advocating honesty Conduct proper guidance and education, timely adjust, supplement and update the content system of ideological and political education so as to enhance the timeliness of the teaching of the "four comprehensive" strategic layout.

Textbooks are not lectures, classroom teaching can not be mechanically based on the syllabus, classroom teaching is thoroughly based on teaching materials, the use of lively language, students love to see the re-creation of forms, that is, we often say that the textbook system to the organic teaching system Conversion. The reason why teacher teaching is the key lies in that only through teaching in the classroom can the contents of the teaching materials be vivid, so that students can enjoy the charm of theory and the power of truth. To prepare a good teaching material is only the basis of teaching, no matter how good the textbook, but also can not replace the teacher's classroom teaching. In the course of teaching "Introduction", we can not just pursue the integrity of teaching system and impart knowledge. The essence of the course of ideological and political theory is to seize the main contents and deepen the Marxist world outlook, outlook on life and values education. 
It can not be imagined that a teacher who has no firm theoretical conviction and correct values can really talk about "Introduction". Such a teacher, even if the language is good again, I am afraid it will "run", it is difficult to really impress students. This is where the key role of teachers is.

\section{The spirit of the Sixth Plenary Session of the "Introduction" teaching teaching recommendations}

In the 2015 revision, keep the original 12 chapters unchanged, adding and adjusting some of the content. First, since the 18th CPC National Congress, General Secretary Xi Jinping has put forward a series of major ideas on governing the state and administration. In particular, it has formed a "four-round strategic layout." In Chapter I, Chapter 3, the theoretical system of socialism with Chinese characteristics ", Adding the latest achievements of the theoretical system of socialism with Chinese characteristics, the latest achievements of the theoretical system of socialism with Chinese characteristics, and the third chapter of Chapter Twelve" Theories of the core of leadership in socialism with Chinese characteristics ", Devoted to "comprehensive and strict governance of the party."

"Full and strict rule of the party" is the deepening of the party building theory in the theoretical system of socialism with Chinese characteristics. The teaching consists of two parts, the practice teaching and the theoretical teaching. In the teaching of theoretical part, I mainly make it clear that the background and scientific connotation of "comprehensive and strict rule of the party".

$\mathrm{Xi}$ Jinping stood at the historical height and clearly put forward the requirement of "completely and strictly administering the party" at the concluding meeting of the CPC's mass line education practice. "Full and strict rule of the party" is an inevitable requirement for the Chinese Communist Party to maintain the purity of nature of the advanced nature and consolidate the ruling status of the Communist Party of China. "Full and strict rule of the party" is also an objective requirement of the CPC to test the international and domestic risks and accomplish the ruling party's mission. Only in the face of the test of international and domestic risks can we "test our exams that our party is going through and will undergo various tests so that our party will never deteriorate" only through the implementation of "full and strict control of the party." [5]

The Scientific Connotation of "Full and Strict Ruling the Party," I read it from two aspects: "comprehensiveness" and "strictness." "All-round" means that the content of governing the party is all-encompassing. It includes all aspects of the party's system, ideology, organization, work style and anti-corruption and advocacy; "All-round means that the subject and object of governing the party are members of the entire Chinese Communist Party; "That is, the process of running the party is accompanied by the administration of the party and the state as a whole." Being strict "means governing the party with more stringent standards. Party rules and regulations are more stringent than the law. The demands on party members are stricter than those for the general public "Full and strict administration of the party" is an important part of "four comprehensiveness" and is the fundamental guarantee for building a well-off society in an all-round way, deepening the reform in an all-round way and administering the country in full accordance with the law.

In the practical teaching part, I mainly have two topics of classic replay and thematic discussion. One of the activities is the classic replay. Organizing students to watch the documentary "Chen Yun's Story" Episode 12, asking students to read the film to write around 800 words "sense of outlook" at the specified time sent to my mailbox. Another activity is from the "development history of the CPC's thought of party building from the fourth generation of the four generations of leaders", "the relationship between the party and the party governance in an all-round and strict manner" and "the relationship between the party and the state in an overall and strict administration of modernization" Point of view, organize students to study thinking and discussion, deepen the understanding of "full and strict rule of the party". Each discussion group writes the result of thought-provoking discussions into a paper and sends it to my email at the specified time. I will submit from the student 


\section{References}

[1] Xu Guangchun. Deep understanding of the "four comprehensive" strategic layout of the major theoretical and practical significance [J]. Xinhua Digest, 2016 (4): 2.

[2] Huang Kunming. Profoundly understand the important meaning of "four comprehensiveness" [J]. Xinhua Digest, 2015 (17): 3.

[3] Hongda Yong. "Four comprehensive" strategic layout of the sociological significance [N]. Guangming Daily, 2016-04-20.

[4] Xi Jinping made important instructions on the work of party building in colleges and universities: Emphasizing the Thought of the Lead People and Leading the Improvement of the Party Building in Colleges and Universities [N]. Guangming Daily, 2014-12-30.

[7] Chen Xuelei.Analysis of innovation of ideological and political education of college students under the strategic layout of "four holistic" [J]. Party Building and Ideological Education, 2015 (7): 17. 